\title{
APLICATION THE DEVELOPMENT OF BALIKPAPAN BAY INDONESIA BASED ON SUSTAINABLE TOURISM
}

\author{
Syahrul KARIM* \\ Hospitality Department, Balikpapan State Polytechnic \\ Indonesia, 76126, Balikpapan, East Kalimantan, e-mail: syahrul.karim@poltekba.ac.id \\ Bambang Jati KUSUMA \\ Hospitality Department, Balikpapan State Polytechnic \\ Indonesia, 76126, Balikpapan, East Kalimantan, e-mail: bambang.jati@poltekba.ac.id \\ Tuatul MAHFUD \\ Hospitality Department, Balikpapan State Polytechnic, \\ Indonesia, 76126, Balikpapan, East Kalimantan, e-mail: tuatul.mahfud@poltekba.ac.id
}

\begin{abstract}
Citation: Karim, S., Kusuma, B. J., \& Mahfud, T. (2019). APPLICATION THE DEVELOPMENT OF BALIKPAPAN BAY BASED ON SUSTAINABLE TOURISM. GeoJournal of Tourism and Geosites, 24(1), 29-38. https://doi.org/10.30892/gtg.24103-340
\end{abstract}

\begin{abstract}
The development of sustainable tourism has become an important issue for every country. Although it has been studied extensively, the study of bay tourism development which is in danger of damage is still limited. The purpose of this study is to (1) investigate the picture of tourism potential in Balikpapan Bay; (2) analyze the concept of sustainable tourism development in Balikpapan Bay; (3) examine the direction of sustainable tourism management policies in Balikpapan Bay as a leading tourist destination. The study method uses a mixed method approach. The results of the study revealed that the Balikpapan Bay area has the potential to be an ecotourism-based tourist area with the presence of marine ecosystems, coral reefs, mangrove forests, duyung (mermaid)/ dugong (dugong dugon), and the existence of 250,000 inhabitants of Balikpapan Bay, 80 percent of whom are fishermen. This concept can simultaneously be a solution in facing the threat of more severe environmental damage, increasing the economy of the local community and preserving the culture of the community. The direction of the development of Balikpapan Bay based on sustainable tourism is the Destination Management Organization (DMO).
\end{abstract}

Keywords: tourism, Balikpapan Bay, sustainable tourism

\section{INTRODUCTION}

The issue of sustainability and sustainable development has become an increasingly important issue for the 21st century. The concept of sustainability requires the conservation

\footnotetext{
* Corresponding author
} 
of resources and elements of equity for current and future generations. Moreover, now it can be concluded that there is international recognition of the need for sustainable development in all industrial sectors in the world. This recognition does not escape the tourism industry sector. Sustainable tourism development (STD) applies elements of sustainable development in the context of tourism and recent years has become a dominant paradigm (Hunter, 1995). In addition, the development of sustainable tourism has also become a strategic issue in every tourism development in each region (Alaeddinoglu \& Can, 2011; Andreyanova \& Ivolga, 2018; Aswita et al., 2018; Dymond, 1997), including the development of bay tourism (Nel \& Binns, 2002; Pham, 2012; Stonich et al., 1995). Although many studies have revealed the importance of sustainable tourism development in the local region, studies of tourism development in the bay area (for example, tourism potential, development concepts, and policy directions) are still few and have not been explicitly discussed.

STD is often interpreted as a triangular interaction between host areas (including social and natural environments), tourists and the tourism industry (Lane, 1994; Müller, 1994). This concept gave birth to various sustainable development ideas such as responsible tourism, alternative tourism, soft tourism, minimum impact tourism, environmentally friendly tourism, and ecotourism ( $\mathrm{Lu} \& \mathrm{Nepal,} \mathrm{2009).} \mathrm{Also,}$ sustainable tourism includes conservation policies, pollution, the use of resources, tourism organizations (institutions), communities, tourists, the private sector and government (Laitamaki et al., 2016). In principle there are four basic principles for the concept of sustainability: (1) the idea of holistic planning and strategy making; (2) community involvement in each process; (3) cultural and environmental preservation then requires human inheritance and biodiversity and (4) development based on the idea that productivity can be maintained in the long term for future generations (UNDP, 2015). In essence, sustainable development is an integrated and organized effort to develop a quality of life by regulating the supply, development, utilization, and maintenance of resources in a sustainable manner (Zolfani et al., 2015). The concept will be well implemented if a good governance system involves active and balanced participation between the government, the private sector, and the community. Thus, sustainable development is not only related to environmental issues but also issues of democracy, human rights, and other broader issues. In fact (Edvardsson \& Enquist, 2008) requires some requirements that must be met to ensure the sustainability of tourism, namely tourists have the willingness to consume tourism services and products selectively. The existence of Balikpapan Bay in the city of Balikpapan, East Kalimantan has the potential to lay the foundation for sustainable tourism management.

The bay, which has historical traces, community culture, natural resources, natural resources, is a great potential to make Balikpapan Bay the leading tourism destination in East Kalimantan. This is in line with East Kalimantan's vision of slowly leaving non-renewable natural resources as regional economic income. Balikpapan Bay region has a watershed area of around 211,456 ha and waters of 16,000 ha. 54 subwatersheds are flowing into the bay, including one of the largest Sei Wain watersheds that have been designated as protected forest of the Balikpapan city government. Also, there are 31 small islands around it (Balikpapan, 2016). This description illustrates that Balikpapan Bay has the potential for local tourism development.

Also, Balikpapan Bay is also a vital economic point for East Kalimantan for export and import activities. A total of 5.130 ha has been transformed into the center of an industrial area known as the Kariangau Industrial Area (KIK), including the existence of an international container port. The development of this industrial area has threatened the local tourism ecosystem, for example, the native animal species of Borneo, the 
Proboscis Monkey with the number reaching 1,400, representing 5\% of yellow-haired primates throughout the world. Besides, there are also about ten species of primates and four types of marine mammals including Irrawaddy dolphins, most of which are found in Balikpapan Bay. Another potential is the existence of mangrove forests covering 2,189 ha (Hardjanto, 2015). Another threat is environmental pollution. Still fresh in our mind, at the end of March 2018, a major disaster occurred in the bay of Balikpapan. Spills of oil spills from Pertamina's pipeline under the seabed contaminate Balikpapan Bay with an area of up to 20,000 ha. This is generated from analysis of Cosmo Sky Med and Sentinel 1a radar satellite data on April 1, 2 and 5, 2018 (Figure 1) (Fajar, 2018).

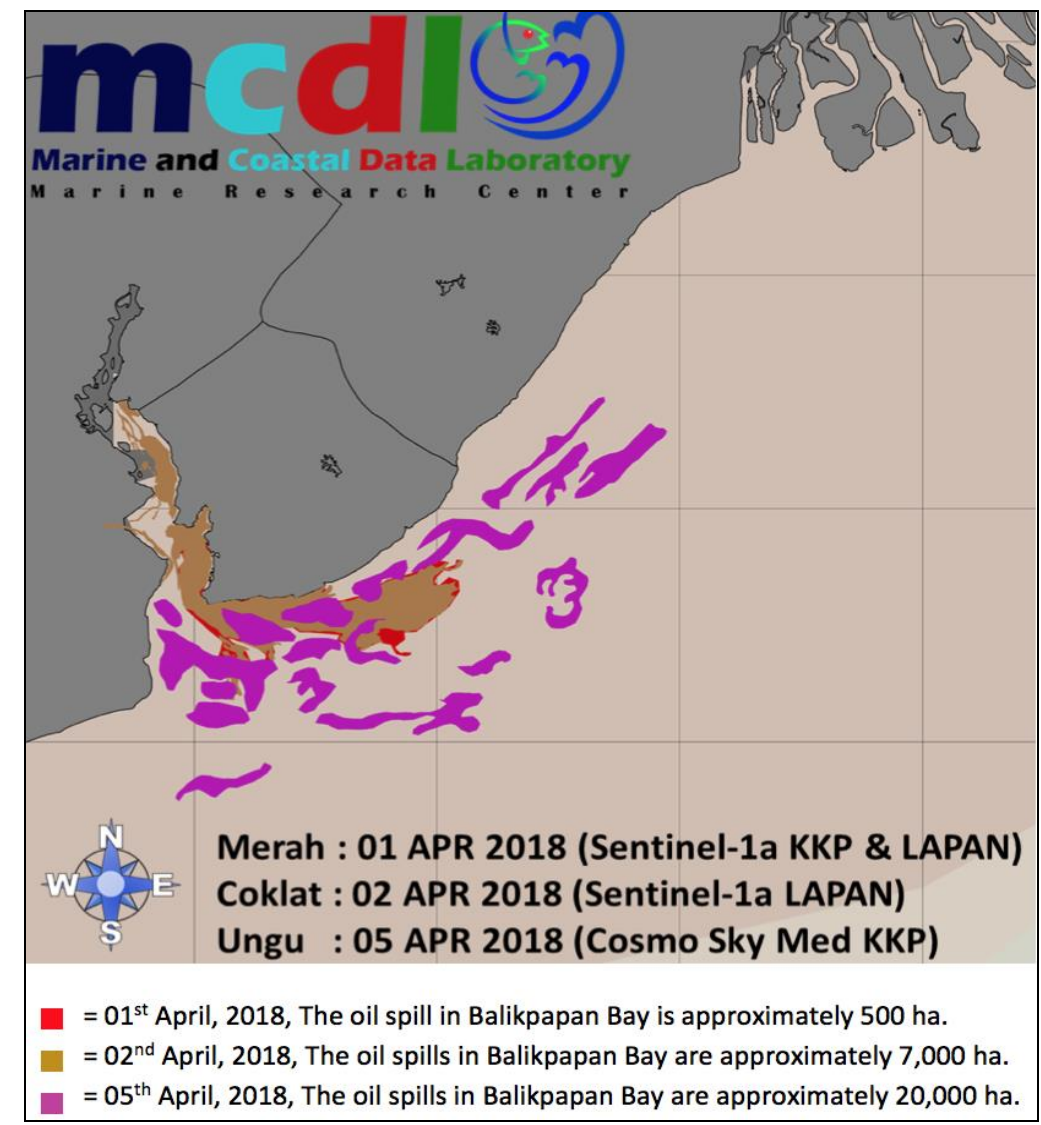

Figure 1. The infographic of oil spill area in Balikpapan Bay, East Kalimantan (Source: Fajar, 2018)

Build this extensive database, and studies are needed to overcome the problem in this study specifically to develop local tourism in Balikpapan Bay. Thus, this study has the following objectives, namely: (1) to investigate the picture of tourism potential in Balikpapan Bay; (2) to analyze the concept of sustainable tourism development in Balikpapan Bay; (3) to analyze the direction of sustainable tourism management policies in Balikpapan Bay as a leading tourist destination.

This study will significantly provide a reference for stakeholders, especially the government of East Kalimantan, Balikpapan, Penajam Paser Utara and Kutai Kartanegara in managing and developing sustainable tourism in Balikpapan Bay. 


\section{METHODS}

The type of research in this study was a descriptive research method with a quantitative-qualitative approach. The researcher intended to describe the development of Balikpapan Bay based on sustainable tourism. The research setting was at Balikpapan Bay. Administratively, Balikpapan Bay is located in Balikpapan City, Penajam Paser Utara Region, and Kutai Kartanegara. The data collection technique and analysis were conducted through direct observations on the object of observation in biophysics data, social, economy, and culture which become the tourism object potential and attraction as well as resources in Balikpapan Bay. Besides, the distribution of questionnaires and interviews with officials were conducted, namely East Kalimantan Provincial Government, Balikpapan City Government, Penajam Paser Utara regency Government, Kutai Kartanegara District, PHRI, ASITA, Environmental NGOs, Universities, and communities around Balikpapan Bay and foreign tourists.

The results of data collection by identifying tourism potential then an empirical descriptive quantitative analysis was carried out to obtain a general picture of potential and tourist attraction. The methods in assessing the tourism potential and objects of tourist attraction were carried out using the assessment criteria that have been determined in the Guidelines for Appraising Objects and Attraction (Attar et al., 2013).

Furthermore, the data was calculated to obtain the score/value of tourism potential using the formula: $\mathrm{S}=\mathrm{N}$ x B Description: $\mathrm{S}=$ score/value, $\mathrm{N}=$ Number of values of elements - criteria, $\mathrm{B}=$ Weight value after obtaining the score each indicator was classified. The classification of assessment was arranged based on the readiness to develop tourism potential; highly potential, potential, less potential, not potential with the formulation of Interval: $S_{\max }-S_{\min }$ : 3. Furthermore, for the development of Balikpapan Bay was analyzed using a SWOT analysis.

\section{RESULTS DISCUSSIONS}

Geographically, the ecosystem of Balikpapan Bay region is located in three regencies namely Balikpapan City, Penajam Paser Utara Regency, and Kutai Kartanegara Regency. All are interconnected one and another. Penajam Paser Utara possesses Balikpapan Bay ecosystem area up to 80 percent, Balikpapan has 17 percent, and 3 percent belongs to Kutai Kartanegara. There are 42 villages from three regencies/cities in this region with a population of around 250 thousand. The people rely their lives on Balikpapan Bay through fishing, fish cages, crab fattening, and aquaculture (Makinuddin, 2010). Balikpapan Bay has waters area of 16.000 hectares. There live diverse endemic animals of Kalimantan such as Pesut (Orcaella brevirostris), sea cow, dolphins, and seagrass. Also, there are also 31 small islands. In the bay margin, various mangrove plants grow with the area of 16.918 ha. Around 15.108 ha of land is located in the region of Penajam Paser Utara (PPU) Regency and 1.810 ha is located in Balikpapan City. The existence of mangrove gave livelihood for long-nosed monkeys or Bekantan (Nasalis larvatus) which are estimated to still number 1.400 (Mahdelany, 2015).

\section{Assessment of Tourism Potential and Object of Tourist Attraction}

There are four criteria need to be met by a tourist attraction to be developed as a tourism destination such as attraction, accessibility, amenities, and institution (Trebicka, 2016). Similarly, Kauppila et al., (2009) stated that the factors that determine the development of a destination include attractions, amenities, and accessibility. These criteria were further developed by the Ministry of Forestry through the assessment of the component of tourism which included attraction, accessibility, amenities, and socio-economic conditions of the local community. This is in line with the sustainable tourism development which puts emphasize on three main aspects such 
as environment, social, and economy. The results of questionnaire and interview on the potentials of Balikpapan Bay showed that there are several places which are potential to be tourist attraction such as small islands, sea cow, mangrove forest, Bekantan, and Gersik Fishermen's village as concluded in Table 1.

Table 1. The Assessment Results of Balikpapan Bay's components of tourism

(Data source: The processed primary data, 2018)

\begin{tabular}{|c|c|c|c|c|c|c|}
\hline Variable & $\begin{array}{l}\text { Max } \\
\text { Score }\end{array}$ & $\begin{array}{l}\text { Min } \\
\text { Score }\end{array}$ & Interval & $\begin{array}{l}\text { Appropriateness } \\
\text { Criteria }\end{array}$ & $\begin{array}{l}\text { Total } \\
\text { Score }\end{array}$ & Descriptions \\
\hline Attraction & 1080 & 360 & 240 & $\begin{array}{c}\text { Appropriate: } \\
840-1080 \\
\text { Not yet appropriate: } \\
\text { 600-840 } \\
\text { Inappropriate: }<600\end{array}$ & 900 & Appropriate \\
\hline Accessibility & 750 & 375 & 125 & $\begin{array}{c}\text { Appropriate: } \\
625-750 \\
\text { Not yet appropriate: } \\
500-625 \\
\text { Inappropriate: }<500\end{array}$ & 620 & Inappropriate \\
\hline Amenities & 180 & 60 & 40 & $\begin{array}{c}\text { Appropriate: } \\
140-180 \\
\text { Not yet appropriate: } \\
100-140 \\
\text { Inappropriate: }<100\end{array}$ & 180 & Appropriate \\
\hline $\begin{array}{l}\text { Infrastructure } \\
\text { and Facilities }\end{array}$ & 300 & 60 & 80 & $\begin{array}{c}\text { Appropriate: } \\
220-300 \\
\text { Not yet appropriate: } \\
140-220 \\
\text { Inappropriate: }<140\end{array}$ & 300 & Appropriate \\
\hline Utility Network & 360 & 120 & 80 & $\begin{array}{c}\text { Appropriate: } \\
220-300 \\
\text { Not yet appropriate: } \\
140-220 \\
\text { Inappropriate: }<140\end{array}$ & 360 & Appropriate \\
\hline
\end{tabular}

\section{Tourist Attractions}

The variable of tourist attraction in Table 1 has the value of 900 from the maximum value of 1080. It means that regarding the attractiveness of Balikpapan Bay, it is very feasible or potential to be visited by tourists because tourism is the primary motivation for tourists to pay tourist visits (Corluka et al., 2016). The attraction is the initial capital that allows visitors to come (Attar et al., 2013). The same thing was confirmed by Kauppila et al. (2009) that the main factors that drive tourists to visit tourist destinations are tourist attractions. The element in the tourist attraction variable which has the highest value was the uniqueness of natural resources, the large number of natural resources that stand out, natural tourism activities, and comfort has a maximum value of 180. Respondents give this assessment by the condition of Balikpapan Bay which has desirable natural resources and wealth Such as Pesut (Orcaella brevirostris), dolphins, and seagrass. There are 31 beautiful small islands around Balikpapan Bay (untouched) and grown with 18 varieties of mangroves with an area of 16,918 ha. Also, it is inhabited by 1,400 Bekantan (Mahdelany, 2015).

From the perspective of history and culture, Balikpapan Bay becomes an essential part of the establishment of Balikpapan. The element of cleanliness and security are 
assessed poorly by the respondents with the score of 75 . This is because environmental pollution keeps occurring in Balikpapan Bay. While for the element of security, respondents considered encroachment on mangroves by the people around Balikpapan Bay had not stopped. Mangrove areas are converted into aquacultures and charcoal products. The changes in conservation land status into industrial land were done by local governments from 2,150 ha to 5,130 ha. There is no wonder that there is a horizontal conflict between the company and society with regional government.

\section{Accessibility}

According to March (2004), accessibility refers to the convenience that can be obtained by the visitors in making the trips and entering a location. Two of the several factors that make an area attractive to visitors is the distance between tourist sites and international airports (whether close or far) and access to travel to tourist attractions whether easy and convenient or difficult. The assessment results on accessibility variable in Table 1 only gained the score of 620 which belongs to the category of inappropriate or not potential. The docking element is rated as the lowest by respondents from the five elements. This is due to the unavailability of individual piers made by stakeholders-local governments in facilitating tourist access to the Balikpapan Bay area. Travelers only use the Balikpapan ferry pier-Penajam Paser Utara in two places, Kampung Baru, and Semayang. The same thing happened at Penajam Paser Utara (PPU). Meanwhile, the road condition, distance, types of road, and traveling time from the downtown have the highest score. Balikpapan has an international airport Sultan Aji Muhammad Sulaiman Sepinggan which only takes 30 minutes to Balikpapan Bay port with asphalt roads.

\section{Accommodations}

The accommodation is something provided to fulfill the necessity, for example, a place to stay or a temporary residence for travelers (Trebicka, 2016). The commercial accommodations in the tourism field aimed are looking for profits by offering products or services to the tourists to gain profit. The result of data analysis on the accommodation variable in Table 1 , respondents gave the maximum score of 180 categorized into appropriate. Two sub-elements in the accommodation assessment are the availability of hotels/inns and the number of rooms. This is in line with the condition of Balikpapan as a city of services, trade, and tourism. Data from the East Kalimantan Provincial Tourism Office, (2016) the number of hotels/inns in Balikpapan is 64 units with the number of rooms in total is 5319. The details are, 5-star hotels; 3 units (594 rooms), 4-star hotels; 7 units (1278 rooms), 3-star hotels; 12 units (1581 rooms), 2-star hotels; 3 units (150 rooms), 1-star hotels; 6 units (329 rooms), and non-star hotel35 unit (1387 rooms).

\section{Facilities and Infrastructure}

The destination facilities/ amenities are elements in a destination or associated with a destination that allows tourists to stay in the destination to enjoy or participate in the attractions offered (Martins, 2018). The destination facilities can be restaurants, ca fés, and bars, including transportation and taxi rental services, as well as other services including shops, salon, information center, and others. The result of facilities and infrastructure variable in Table 1 belongs to the appropriate/ potential category with a score of 300. Respondents' assessment of facilities and infrastructure as shown in Table 1 shows that the facilities and infrastructure are available around the Balikpapan Bay tourist destination area. The aspects included in the facilities are the post office, health services, telephone network, and electricity network. The element in infrastructure, restaurant, shopping center, travel service, shop, café, karaoke and pub, souvenir shop, bank, and public transportation.

Based on the Tourism Office's data in East Kalimantan Province (Dinas, 2016), Balikpapan has the second most restaurants in East Kalimantan after Samarinda 981 
units, food service enterprises 23 units, travel agencies 195 units, and gallery 16 units. The number of services gives direct convenience to the tourists.

\section{Utility Network}

Utility network becomes an essential part in developing a tourism area in a region. The utility network in this research consists of three sub-elements namely the electricity network, telephone network, and a clean water network. The respondents assessed the utility network variable in Table 1 is very potent with the score of 360 . Balikpapan Bay has become one of the sources of drinking water for the people of Balikpapan city, that is, the existence of the Wain River protected the forest. Since 1972 this freshwater has been used by state-owned companies-Pertamina for operational activities and employees with an average water use of $450-750 \mathrm{~m} 3$ per hour or $\pm 25 \%$ of the total volume of freshwater commonly used by all households in Balikpapan (Rizkiyah, Sugianto, \& Purwanto, 2016). This means the water in Balikpapan Bay is available for tourists if it is well-managed.

\section{SWOT Analysis}

The results of tourist attraction in the Balikpapan Bay showed in Table 1 were combined with the results of interview and observation to be further analyzed using SWOT. This was conducted to find out further about the strengths, weaknesses, opportunities, and challenges of Balikpapan Bay at present and in the future.

\section{Strengths}

Balikpapan Bay has unique natural resources which do not exist in other bay areas in Indonesia. There live various flora and fauna. Balikpapan Bay is a habitat of Proboscis monkey (Nasalis larvatus) and contributes to five percent of the population from around the world which is estimated at 20-25 thousand individuals. There live more than 100 other types of animals such as the Kalimantan orangutan (Pongo pygmaeus), Kalimantan Owa (Hylobates muelleri), freshwater dolphins (Orcaella brevirostris), sea cow (Dugong dugon), to sun bears (Helarctos malayanus). There are more than 300 species of birds in this area namely Tokhtor Kalimantan (Carpococcyx radiceus radiceus) and Storm Stork (Ciconia stormi) (Fajar, 2018).

For Flora, Balikpapan Bay region is a primary tropical forest, regeneration of secondary tropical rainforests, mangrove forests, swamps, rocky lands, coral reefs, seaweed, and shallow seas. The secondary forest that connects these forest boundaries with other vital forests is the conservation area of the Soeharto Hill forest to the northeast and Mount Meratus to the southwest. The ecosystem of waters connects Makassar Strait to the east. From the aspects of social and cultural, around 250.000 local people reside on the Balikpapan Bay coastal and making the Balikpapan Bay as the primary source of livelihood in which most of them are fishermen. There are five traditional fishing villages namely Gersik, Jenebora, Lango Beach, Maridan, and Mentawir with the uniqueness of each village. Regarding accessibility, Balikpapan Bay is supported by Sultan Aji Muhammad Sulaiman Sepinggan Balikpapan International Airport with a distance of about 30 minutes. The availability of hotels, restaurants, and touristic service facilities are complete in Balikpapan city.

\section{Weaknesses}

The development of industry and palm tree plantation in coastal and upstream areas in Balikpapan Bay gives adverse effects on the ecosystem sustainability in the future. Not to mention the existence of environmental pollution, forest destruction, sedimentation. Especially with the existence of the Balikpapan city government policy to increase the extent of the Kariangau Industrial Area (KIA) so that the existence of Balikpapan Bay as a strategic and high-value area can be degraded quickly and uncontrollably. Also, concerning accessibility issue includes unavailability of a particular port and specially-designed boats for the tourist. 


\section{Opportunities}

The number of local tourist visits to East Kalimantan in 2016 reaching 5 million people and 2.3 million people was visiting Balikpapan. There were 24 thousand foreign tourists who visited East Kalimantan, and 9.223 people visited Balikpapan. The high interest in visiting East Kalimantan is the primary capital in creating tourism as a new attraction. About 70 percent of the interest in tourist visits is ecotourism, which is visiting the island of Derawan, Maratua, Sangalaki. The rest can be visiting Kutai National Park, Gersik Luwai, and Bukit Bengkirai as well as Samboja Lodge Research Center/ Borneo Orangutan Survival (BOS).

\section{Challenges}

The threats to Balikpapan Bay in the future are there is a transfer of land functions from protected areas to plantation cultivation areas, aquaculture, agriculture, and residential area. The increased population has implications for the space required. The threats to transfer livelihoods as a result of overtaking space functions, poor conditions of residential infrastructure (clean water, drainage, and waste coverage), low quality of human resources, and water pollution due to the factory and household waste disposal. The threat to rare animal's lives (Pesut and sea cow) includes the silting of the estuary, especially the one used as a boat shipping channel. There is a tendency to open mangrove areas for aquaculture, industrial and residential areas, and other activities. The society's behavior often damages the conservational region and also the construction of a new building and residences which exceeds the coastal boundaries (Balikpapan, 2016).

\section{Development of Balikpapan Bay Based on Sustainable Tourism}

Sustainable tourism implied that the growth of the economy and the conservation of environmental quality had strengthened each other. The essence of this form of development is a stable relationship between human and natural activities, which does not decrease the prospect of future generation to enjoy the quality of life at least as best as we do. Based on the analysis above, Balikpapan Bay can be developed as ecotourism area in which a part of the development of sustainable tourism. Ecotourism is one type of sustainable tourism that makes the community as the main subject which in principle conserves and utilizes the nature and culture of local communities and as a means of educating tourists. It is expected that in practice there will be environmental and cultural sustainability, not only on objects or attractions but when tourists return to their place of origin. On the economic aspect, it can improve the economy of local people and regional government through locally-generated revenue (LGR) since there is a large-scale employment opportunity.

\section{Management Policy of Balikpapan Bay}

Balikpapan Bay has complex problems with substantial natural potentials. Geographically, it is included in three regions which are Penajam Paser Utara, Balikpapan, Kutai Kartanegara. Therefore, in realizing as a tourism-based tourist attraction, the implementation of policies can be implemented through the concept of Destination Management Organization (DMO). DMO is an integrated tourism management system that has the completeness as a system (Gryszel, 2010). With the application of this concept all elements can be involved in the management of Balikpapan Bay, starting from the community, the government of three regions, Penajam Paser Utara, Balikpapan, Kutai Kartanegara, East Kalimantan Province, Ministry of Tourism, private elements incorporated in PHRI, ASITA and companies operating in the Gulf Balikpapan, Universities and NGOs. The involvement of all parties is expected to be able to contribute to the regional development. As stated by Kim, Jang, \& Morrison (2011) the completeness of DMO can be the economic driver, community marketer, industry coordinator, quasi-public representative, builder of community pride with an improvement in the quality of life. 


\section{CONCLUSION}

Principally, Balikpapan Bay is highly appropriate to be developed as a leading tourism object in East Kalimantan. The assets owned by Balikpapan Bay can be used as nature-based tourism, ecotourism, marine tourism, community-based tourism, or bay tourism which combines natural and aquatic elements. The concept is a part of sustainable tourism. At the policy level, the concept of Destination Management Organization can be applied by involving all elements and forming an integrated institution.

\section{Acknowledgements}

The author would like to thank the East Kalimantan provincial government, the city of Balikpapan, Kutai Kartanegara Regency, North Penajam Paser District, NGOs, and the Ministry of Research and Technology Indonesia, who have provided funding through the 2018 DPRM so that the research is carried out well.

\section{REFERENCES}

Alaeddinoglu, F., \& Can, A. S. (2011). Identification and classification of nature-based tourism resources: Western Lake Van basin, Turkey. In Procedia - Social and Behavioral Sciences (Vol. 19, pp. 198-207), Elsevier B.V. https://doi.org/10.1016/j.sbspro.2011.05.124.

Andreyanova, S., \& Ivolga, A. (2018). The tourism potential of the North Caucasus: The formation, characteristics and development prospects. Geojournal of Tourism and Geosites, 22(2), 347-358.

Aswita, D., Suryadarma, I. G. P., \& Suyanto, S. (2018). Local wisdom of sabang island society (Aceh, Indonesia) in building ecological intelligence to support sustainable tourism. Geojournal of Tourism and Geosites, 22(2), 393-402. https://doi.org/10.30892/gtg.22210-297.

Attar, M., Hakim, L., \& Yanuwiadi, B. (2013). Potential Analysis and Direction of Ecotourism Village Development Policy Strategies in Bumiaji District - Batu City (Indonesian version). Journal of Indonesian Tourism and Development Studies, 1(2), 68-78. Retrieved from http://jitode.ub.ac.id/index.php/jitode/article/view/112.

Balikpapan, B. K. (2016). Final report on the preparation of strategic plans for the management of coastal and small island areas (RSWP-3-K) (Indonesian version). Kota Balikpapan.

Ćorluka, G., Mikinac, K., \& Milenkovska, A. (2016). Classification of tourist season in costal tourism. UTMS Journal of Economics, 7(1), 71-83.

Dinas Pariwita Provinsi Kaltim. (2016). Distribution data of tourist and accommodation objects in East Kalimantan (Indonesian version).

Dymond, S. J. (1997). Indicators of sustainable tourism in New Zealand: A local government perspective. Journal of Sustainable Tourism, 5(4), 279-293. https://doi.org/10.1080/ 09669589708667292.

Edvardsson, B., \& Enquist, B. (2008). Values-based service for sustainable business -Lessons from the retailers IKEA, Starbucks, H \& M and Body Shop. 11th QMOD Conference. Quality Management and Organizational Development Attaining Sustainability From Organizational Excellence to SustainAble Excellence, 1.

Fajar, J. (2018). Apparently Balikpapan Bay has often been contaminated with oil (Indonesian version). Retrieved October 14, 2018, from http://www.mongabay.co.id/2018/04/o9/ ternyata-teluk-balikpapan-sudah-sering-tercemar-minyak-kok-bisa/.

Gryszel, P. (2010). Destination Management Organization and Creating the Quality of Tourist Product of a Region, 372-375.

Hardjanto, Y. (2015). Balikpapan Bay which continues to be eroded due to industrial expansion (Indonesian version). Retrieved October 14, 2018, from http://www.mongabay.co.id/ 2015/04/o1/teluk-balikpapan-yang-terus-tergerus-akibat-ekspansi-industri/.

Hunter, C. J. (1995). On the need to re-conceptualise sustainable tourism development. Journal of Sustainable Tourism, 3(3), 155-165. https://doi.org/10.1080/09669589509510720.

Kauppila, P., Saarinen, J., \& Leinonen, R. (2009). Sustainable tourism planning and regional development in peripheries: A Nordic view. Scandinavian Journal of Hospitality and Tourism, 9(4), 424-435. https://doi.org/10.1080/15022250903175274. 
Kim, D. Y., Jang, S., \& Morrison, A. M. (2011). Factors affecting organizational information technology acceptance: A comparison of convention and visitor bureaus and meeting planners in the United States. Journal of Convention and Event Tourism, 12(1), 1-24. https://doi.org/10.1080/15470148.2010.551291.

Laitamaki, J., Tada, M., Liu, S., Setyady, N., Vatcharasoontorn, N., \& Zheng, F. (2016). Sustainable tourism development frameworks and best practices: Implications for the Cuban Tourism Industry. Managing Global Transitions, 14(1), 7-29.

Lane, B. (1994). Sustainable rural tourism strategies: A tool for development and conservation. Journal of Sustainable Tourism, 2(1-2), 102-111. https://doi.org/10.1080/09669589409510687

Lu, J., \& Nepal, S. K. (2009). Sustainable tourism research : an analysis of papers published in the Journal of Sustainable Tourism. Journal of Sustainable Tourism, 17(1), 5-16. https://doi.org/10.1080/o9669580802582480.

Mahdelany. (2015). Environmental Conflicts in Port Cities. Gadjah Mada University, Gadjah Mada University. https://doi.org/10.18276/os.2016.4-03.

Makinuddin, N. (2010). Bridge of balang island: "Slilit" between green borneo and presidential promise (Indonesian version). Retrieved October 15, 2018, from https://telukbalikpapan. wordpress.com.

March, B. R. (2004). A marketing-oriented tool to assess destination competitiveness. Australia: CRC for Sustainable Tourism Pty Ltd.

Martins, M. (2018). Tourism Planning and Tourismphobia : An Analysis of the Strategic Tourism Plan of Barcelona 2010-2015. Journal of Tourism, Heritage \& Services Marketing, 4(1), 3-7. https://doi.org/http://doi.org/10.5281/zenodo.1247519.

Müller, H. (1994). The thorny path to sustainable tourism development. Journal of Sustainable Tourism, 2(3), 131-136. https://doi.org/10.1080/09669589409510690.

Nel, E., \& Binns, T. (2002). Place Marketing, Tourism Promotion, and Community based Local Economic Development in Post-Apartheid South Africa: The Case of Still Bay-The "Bay of Sleeping Beauty." Urban Affairs Review, 38(2), 184-208. https://doi.org/10.1177/ 107808702762484088.

Pham, L. (2012). Tourism Impacts and Support for Tourism Development in Ha Long Bay, Vietnam: An Examination of Residents' Perceptions. Asia Social Science, 8(8).

Rizkiyah, R., Sugianto, D. N., \& Purwanto, P. (2016). Study of Distribution Patterns Hot waste PT. Pertamina Up V Balikpapan (Indonesian version). Buletin Oseanografi Marina, 5(1), 1-13.

Stonich, S. C., Sorensen, J. H., \& Hundt, A. (1995). Ethnicity, class, and gender in tourism development: The case of the Bay Islands, Honduras. Journal of Sustainable Tourism, 3(1), 1-28. https://doi.org/10.1080/09669589509510705.

Trebicka, B. (2016). Tourism as a multiplier effect in economy : the case of Albania. International Journal of Business and Management Invention, 5(1), 17-21.

Zolfani, S. H., Sedaghat, M., Maknoon, R., \& Zavadskas, E. K. (2015). Sustainable tourism: A comprehensive literature review on frameworks and applications. Economic ResearchEkonomska Istrazivanja, 28(1), 1-30. https://doi.org/10.1080/1331677X.2014.995895

** UNDP. (2015). Indicators and Data Mapping to Measure Sustainable Development Goals (SDGs ) Targets.

Submitted:

09.10.2018
Revised:

10.12.2018
Accepted and published online 12.12.2018 